\title{
First discovery of a Devetakia species (Gastropoda: Hydrobiidae) from the Rhodopes Mountains, Bulgaria
}

\author{
Dilian Georgiev $^{1}$, Ivaylo Dedov ${ }^{2}$, Mila Taseva ${ }^{3}$ \\ (1) Department of Ecology and Environmental Conservation, University of Plovdiv, 24 Tsar Assen Street, 4000 Plovdiv, \\ Bulgaria, diliangeorgiev@gmail.com $\sim$; https://orcid.org/0000-0003-2885-4895 [ \\ (2) [Corresponding author] Institute of Biodiversity and Ecosystem Research, Bulgarian Academy of Sciences, 2 Gagarin \\ Street, 1113 Sofia, Bulgaria, idedov@gmail.com $\backsim$; https://orcid.org/0000-0003-4445-359X 【 \\ (3) Institute of Biodiversity and Ecosystem Research, Bulgarian Academy of Sciences, 1 Tsar Osvoboditel Blvd, 1000 Sofia, \\ Bulgaria,m.barrein@gmail.com
}

http://zoobank.org/8FB98C93-F707-4643-BD6A-4FD0EAC8F7F8[ [

\begin{abstract}
A new species of the genus Devetakia, Devetakia apostoloui n. sp., is described from Vucha River, South Bulgaria. The new species is the first member of the genus and the first species from ancient hydrobiid clade from the region of Western Rhodopes.
\end{abstract}

Keywords: ancient origin, identification key, new species

\section{Introduction}

Bulgaria is well known as a hot spot of species diversity of the spring dwelling and stygobiotic snails of the superfamily Hydrobioidea (Georgiev \& Hubenov, 2013). On its territory there is unique ancient clade of stygobiotic snails including and some endemic genera (Osikowski et al., 2017). Even the hydrobiid fauna of Bulgaria is relatively well known there are and some still uninvestigated water caves and karstic springs which can hold some new species to science.

Till now the only stygobiotic species known from the Rhodopes Mts were these from the genus Bythinella which are "young species" of Pleistocene origin (Osikowski et al., 2015). In this paper we describe the first known stygobiotic species of the "ancient clade" (according Osikowski et al., 2017) from this area.

\section{Materials and methods}

The new species was collected in Vucha River $\left(\mathrm{N} 42.03674^{\circ} \mathrm{E} 024.46834^{\circ}, 250 \mathrm{~m}\right)$. The sample was collected with standard hydrobiological hand net with $500 \mu \mathrm{m}$ mesh size (according to ISO 10870:2012: International Organization for Standardization, 2012). The sampling followed the "multi-habitat" procedure of Cheshmedjiev et al. (2011), which is an adapted version of AQEM/STAR methodology (AQEM Consortium, 2002) for local conditions. Three empty shells of the new species were collected. The measurements of shells of the new species were taken under a stereo microscope with an ocular scale and transformed to millimetres.

Material was deposited in the mollusc collection of the Institute of Biodiversity and Ecosystem Research, Bulgarian Academy of Sciences, Sofia (IBER-ID). Used abbreviations: AD - aperture diameter, AH aperture height, Nw - number of whorls, SD - shell diameter, $\mathrm{SH}$ - shell height.

\section{Results}

Genus Devetakia Georgiev \& Glöer 2011

Type species: Devetakia krushunica Georgiev \& Glöer 2011 


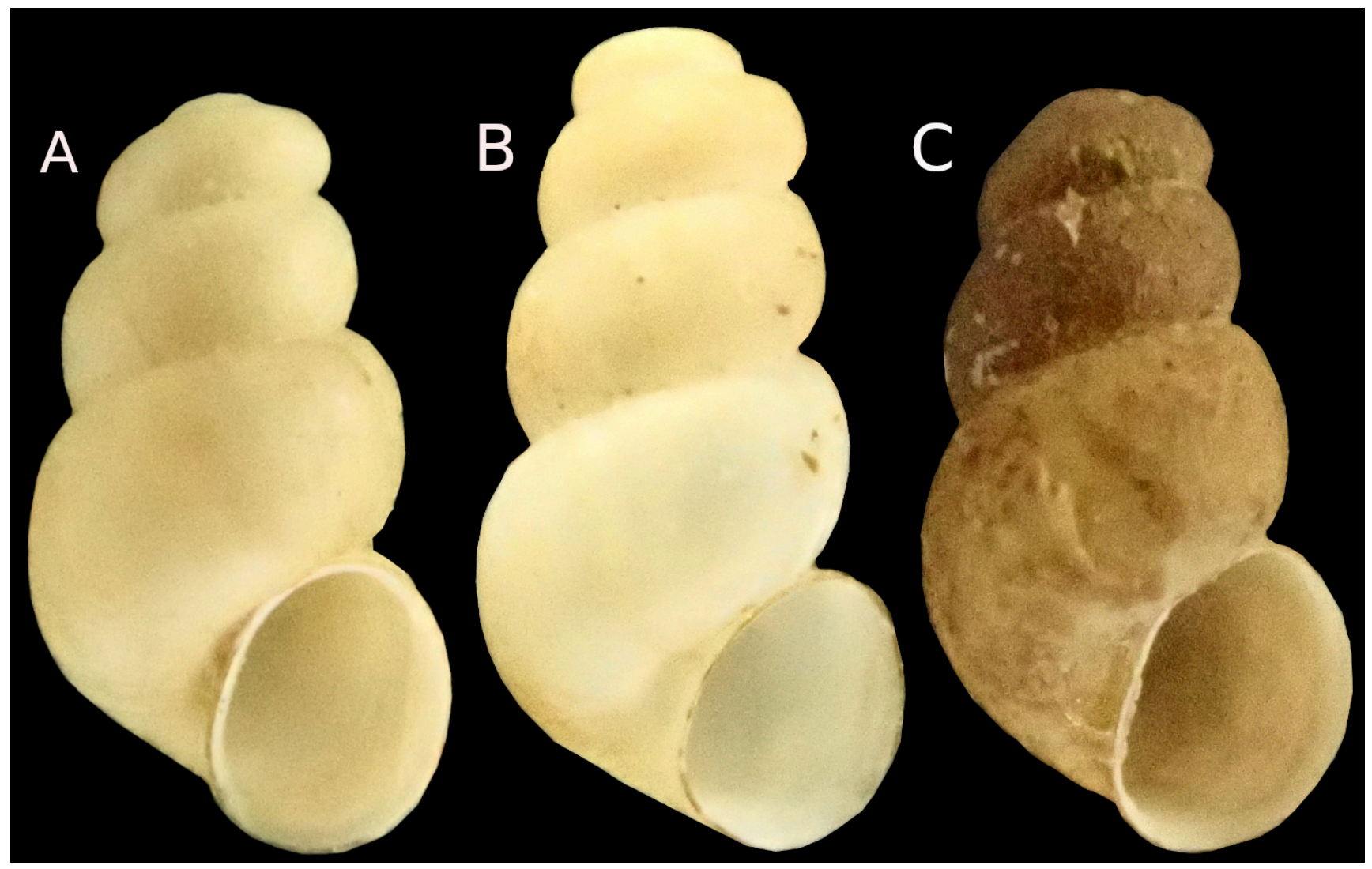

Fig. 1. Devetakia apostoloui n. sp. - holotype (A) and paratypes (B, C).

The shell is dextral, conical, very small (around $2 \mathrm{~mm}$ in height) with an obtuse apex. The shell surface is shining and has fine irregular growth lines. It has regularly growing convex whorls. The aperture has a regular round shape and a simple outer lip. The umbilicus is open and narrow (Georgiev \& Glöer, 2011).

Additional data: Shell: could be conical to almost cylindrical, translucent, fragile, with a translucent and thin operculum. Soft body: The animal is entirely pigmentless, the tentacles are short, slightly passing over the snout length, and are without any eyes. Penis morphology: The penis is short, situated far behind the neck. It has a broad, cylindrical base, and a flat leaflike distal part with sharply pointed apex (Georgiev, 2012; Georgiev \& Glöer, 2015).

The genus is well defined anatomically and genetically (see Georgiev et al., 2017) and is most closely related to the genera Balkanica Georgiev 2017 and Balkanospeum Georgiev 2017, known from the cave system of Machanov Trap-Yantra (Osikowski et al., 2017).
Four species known: D. krushunica, Devetakia pandurskii Georgiev \& Glöer 2011, Devetakia mandrica Georgiev 2012, Devetakia veselinae Georgiev \& Glöer 2015.

\section{Devetakia apostoloui $\mathrm{n} . \mathrm{sp}$.}

Material examined: 3 shells, from the type locality, leg. M. Taseva.

Holotype: ID-2060, Paratypes: 2 specimens (ID-2060/2; ID-2060/3)

Locus typicus: Bulgaria, Vucha River, in the Krichim Town, under WEC Krichim, after HPS, 10.IX.2019, N42.03674 E024.46834, 250 m.

Etymology: Named after Dr Apostolos Apostolou, ichthyologist at the Institute of Biodiversity and Ecosystem Research, Bulgarian Academy of Sciences, Sofia, who show us the collecting spot.

Description: The shell is very small, elongate-conical to almost cylindrical with 3.5-4 rounded whorls 
Tab. 1. Devetakia apostoloui n. sp. - specimens dimensions.

\begin{tabular}{llllll} 
& Nw & Hs & Ds & Ha & Da \\
\hline holotype (A) & 3.5 & 1.98 & 1.08 & 0.72 & 0.57 \\
\hline paratype (B) & 4 & 2.07 & 1.08 & 0.66 & 0.6 \\
\hline paratype (C) & 3.5 & 1.95 & 1.05 & 0.69 & 0.54
\end{tabular}

that have shining surface (Fig. 1A-C). The apex is rounded, the umbilicus is open. The aperture is slightly ovoid with a simple lip. The operculum and the soft body are unknown. $\mathrm{SH}=1.95-2.07 \mathrm{~mm}, \mathrm{SD}=$ 1.05-1.08 mm (Tab. 1).

Diagnosis: Devetakia apostoloui $\mathrm{n}$. sp. differs from $D$. veselinae and $D$. mandrica by its more conical shell. From D. krushunica it differs by its larger size. The new species is most similar to $D$. pandurskii by its external view and size but its shell is with lower whorl number (4.5 in D. pandurskii).

Ecology and distribution: Known only from the type locality - deposits of Vucha River at Krichim Town. Knowing that the Devetakia species are strictly stygobiotic it can be supposed that D. apostoloui $\mathrm{n}$. sp. inhabits underground waters at this area, and some empty shells were driven out at the surface waters by a spring somewhere upland the locality of finding.

As a result of our study we propose an identification key to the species of the genus Devetakia:

1. The shell is conical

- The shell is slightly conical to almost cylindrical 3

2. Shell height $<1.9 \mathrm{~mm}$

D. krushunica

- Shell height $>1.9 \mathrm{~mm}$

4

3. Shell height $<1.7 \mathrm{~mm}$

D. veselinae

- Shell height $>1.7 \mathrm{~mm}$

D. mandrica

4. Whorls 4.5

- Whorls 3.5-4

D. pandurskii

D. apostoloui n. sp.
Balkan area") (D. pandurskii, D. krushunica, D. mandrica), one in west side of the country near the Serbian border (D. veselinae), and one at north slopes of the Rhodopes (D. apostoloui n. sp.). All these are separated by some geographic barriers as high mountains and/or plane large lowlands.

If we accept the theory of the marine origin of the genus, the first isolation of the populations of the predecessor of the Devetakia species possibly occurred during the late Eocene, when a large part of Bulgaria was already a dry land and north and south Bulgaria was divided by the Stara Planina Mts ridge. During the Miocene, lakes of various sizes existed in the areas of the species known south of this mountain chain (Krstić et al., 2012). However exchange of genetic materials between these population cannot be excluded because of some passive dispersal of individuals by migrating birds, which is common for the recent saltwater Hydrobia ulvae (van Leeuwen, 2012).

Osikowski et al. (2017) estimated the origin of the Bulgarian subterranean hydrobiid clade by using molecular clock for COI at approximately 7-6.75 Mya. Then, probably after the disappearance not only of the large lakes and the sea, but also of many small surface waters, such as rivers, the current stygobionts entered into the ground waters through springs in the karstic areas. After extinction of the ancestral surface population, subterranean populations evolved in allopatry. According same authors, this event was most probably caused by the climatic draught shift associated with the Messinian Salinity Crisis (5.96-5.33 Mya).

Our finding of an isolated population of a new species from the Bulgarian ancient hydrobiid clade at the northern slope of the Rhodopes is in accordance of the ancient lakes theories and the "climatic-relict" hypothesis for the speciation of these taxa (Radoman, 1985; Krstić et al., 2012; Osikowski et al., 2017).

\section{Discussion}

It is considered that the endemic Balkan Hydrobioidea are with an ancient marine origin. It is proposed that their ancestors lived in the Eocene and Miocene saltwater seas located on the territory of the current Balkan Peninsula (Radoman, 1985).

It is evident that the genus Devetakia has a disjunct distribution. All known species were found in hilly, semi-mountain areas: three species of north Bulgaria at the foothills of Stara Planina Mts (so called "Pre-

\section{References}

AQEM Consortium 2002 Manual for the application of the AQEM System. A comprehensive method to assess European streams using benthic macroinvertebrates, developed for the purpose of the Water Framework Directive. Duisburg, Germany: AQEM Consortium.

Cheshmedjiev S., Soufi R., Vidinova Y., Tyufekchieva V., Yaneva I., Uzunov Y., Varadinova E. 2011 Multi-habitat sampling method for benthic 
macroinvertebrate communities in different river types in Bulgaria. Water Research and Management 1 (3): 55-58.

Georgiev D. 2012 New Taxa of Hydrobiidae (Gastropoda: Risooidea) from Bulgarian Cave and Spring Waters. Acta Zoologica Bulgarica 64 (2): 113-121.

Georgiev D., Glöer P. 2011 Two New Species of a New Genus Devetakia gen. n. (Gastropoda: Hydrobiidae) from the Caves of Devetashko Plateau, North Bulgaria. Acta Zoologica Bulgarica 63 (1): $11-15$.

Georgiev D., Glöer P. 2015 Two new stygobiont snail species (Gastropoda, Hydrobiidae) from a spring in West Bulgaria. Ecologica Montenegrina 2 (2): 93-97.

Georgiev D., Hubenov Z. 2013 The freshwater snails (Mollusca: Gastropoda) of Bulgaria: updated checklist of species and distributional data. Folia Malacologica 21 (4): 237-263.

Georgiev D., Osikowski A., Hofman S., Rysiewska A., Falniowski A. 2017 Contribution to the morphology of the Bulgarian stygobiont Truncatelloidea (Caenogastropoda). Folia Malacologica 25 (1): 1525.
Krstić N., Savić L., Jovanović G. 2012 The Neogene Lakes on the Balkan Land. Annales Géologiques de la Péninsule Balkanique 73: 37-60.

Osikowski A., Georgiev D., Hofman S., Falniowski A. 2015 Does the genetic structure of spring snail Bythinella (Caenogastropoda, Truncatelloidea) in Bulgaria reflect geological history? ZooKeys 518: 67-86.

Osikowski A., Hofman S., Georgiev D., Rysiewska A., Falniowski A. 2017 Unique, Ancient Stygobiont Clade of Hydrobiidae (Truncatelloidea) in Bulgaria: the Origin of Cave Fauna. Folia Biologica 65 (2): 79-93.

Radoman P. 1985 Hydrobioidea, a superfamily of Prosobranchia (Gastropoda) II. Origin, zoogeography, evolution in the Balkans and Asia Minor. Monographs, Institute of Zoology (Faculty of Science), Beograd 1 (1): 1-173.

van Leeuwen Ch., van der Velde G., van Lith B., Klaassen M. 2012 Experimental Quantification of Long Distance Dispersal Potential of Aquatic Snails in the Gut of Migratory Birds. PLOS One 7 (3): e32292.

https://doi.org/10.1371/journal.pone.0032292 〔 